\title{
Identifikasi Bakteri Endofit Daun Ficus Minahassae (Teijsm. \& De Vriese) Miq. Berdasarkan Gen 16s rRNA.)
}

Yosua Theofani Linelejana, Stella Deiby Umboha*, Trina Ekawati Talleia* Jurusan Biologi, FMIPA, Unsrat, Manado

\begin{tabular}{l} 
K A T A K U N C I \\
\hline Bakteri Endofit \\
Ficus minahassae \\
$16 S$ rRNA \\
Brachybacterium muris \\
Pseudacidovorax intermedius.
\end{tabular}

KE Y W O R D endophytic bacteria

Ficus minahassae 16S rRNA

Brachybacterium muris Pseudacidovorax intermedius.

\begin{abstract}
A B S T R A K
Bakteri endofit telah ditemukan hampir di semua tumbuhan yang telah diteliti. Bakteri-bakteri ini mengkolonisasi jaringan internal tumbuhan inang. Di Sulawesi Utara terdapat salah satu tumbuhan ara, yaitu Ficus minahassae, yang hanya tumbuh lokal di daerah ini dan Filipina. Tujuan dari penelitian ini yaitu untuk mengidentifikasi dari bakteri endofit yang mendiami daun F. minahassae. Isolasi bakteri endofit dilakukan dengan menebarkan ekstrak daun yang steril di atas permukaan media Nutrient Agar. Isolat murni yang diperoleh diidentifikasi menggunakan penanda gen $16 S$ rRNA. Dari hasil penanaman ekstrak daun F. minahassae diperoleh dua isolat, yaitu YL1 yang koloninya berwarna kuning, dan YL2 yang koloningnya berwarna krem. Dengan melakukan proses BLAST di GenBank, YL1 memiliki kemiripan 100 \% dengan Brachybacterium muris, sedangkan YL2 memiliki kemiripan 99 \% dengan Pseudacidovorax intermedius. Analisis filogenetik yang dilakukan menggunakan metode UPGMA yang terintegrasi pada piranti lunak Geneious memperlihatkan perbedaan taksa dari bakteri endofit yang ditemukan pada daun $F$. minahassae.

A B S T R A C T

Endophytic bacteria have been found in virtually every plant studied. These bacteria colonize the internal tissue of the host plant. In North Sulawesi there is a fig plant named Ficus minahassae which is endemic to the area and the Philippines. This research was aimed to identify of the endophytic bacteria inhabit the endosphere of the leaf of $F$. minahassae. Isolation of endophytic bacteria was performed by spreading the sterile leaf extract onto NA media. The pure isolates were identified using $16 \mathrm{~S}$ rRNA gene marker. There were two isolates, designated as YL1 and YL2, were isolate from the leaf of $F$. minahassae. The color of isolate YL1 was yellowish and YL2 was creme. Using BLAST nucleotide, YL1 showed $100 \%$ similarity with Brachybacterium muris, and YL2 showed $99 \%$ similarity with Pseudacidovorax intermedius. Phylogenetic analysis performed using UPGMA method integrated on Geneious software showed different taxa from endophytic bacteria found on F. minahassae leaf.
\end{abstract}

TERSEDIA ONLINE

01 Agustus 2018

1. Pendahuluan

Bagian dalam jaringan (endosfir) tumbuhan memiliki berbagai jenis komunitas mikroba. Menurut Kandel et al. (2017) terdapat konsensus bahwa komunitas bakteri ini memiliki kontribusi yang signifikan terhadap kesehatan tumbuhan. Strobel dan Daisy (2003) menyatakan bahwa dari sekitar 300.000 jenis tumbuhan, setidaknya masing-masing jenis memiliki satu atau lebih mikroba endofit. Endofit didefinisikan sebagai mikroorganisme seperti bakteri dan fungi yang mendiami endosfir tumbuhan, baik di akar, daun, maupun batang, tanpa menyebabkan gejala yang merugikan bagi tumbuhan inang (Wilson et al., 1995).

Identifikasi bakteri endofit dapat dilakukan secara konvensional (mikrobiologis) maupun 
molekuler. Identifikasi secara konvensional memerlukan pengetahuan mengenai karakteristik morfologi dan biokimiawi dari bakteri tersebut. Identifikasi secara molekuler memerlukan penanda yang digunakan secara universal. Penanda universal yang digunakan untuk mengidentifikasi bakteri endofit yaitu gen $16 S$ rRNA. Penanda ini sering digunakan untuk mempelajari taksonomi dari bakteri yang belum diketahui jenisnya (Janda dan Abbott, 2007) dan rekonstruksi pohon filogenetiknya karena laju evolusi daerah pada gen ini rendah (Woese dan Fox, 1977). Menurut Radji (2005), kebanyakan bakteri endofit menghasilkan metabolit sekunder yang bermanfaat bagi kesehatan. Meskipun demikian, kemampuan senyawa aktif dari bakteri-bakteri endofit tumbuhan masih perlu dilakukan karena memungkinkan untuk mendapatkan strain yang baru yang memiliki potensi untuk dieksplorasi lebih lanjut (Muzzamal et al. 2011).

Beberapa penelitian melaporkan bahwa bakteri endofit dapat juga ditemukan pada tumbuhan ara (Ficus sp.), sebagai contoh pada F. carica (Ma et al., 2016) dan F. racemosa (Smita dan Dipak, 2015). Salah satu contoh tumbuhan ara lokal yang ditemukan di Sulawesi Utara yaitu F. Minahassae (Teijsm dan de Vriese) Miq. Oleh masyarakat lokal, tumbuhan ini disebut langusei. Tumbuhan ini dapat dijumpai di hutan-hutan primer, terutama di sepanjang sungai, sampai dengan ketinggian lokasi 135 dari permukaan laut. Oleh sebab itu, penelitian ini difokuskan untuk mengidentifikasi bakteri endofit pada langusei.

\section{Material dan Metode \\ Alat dan Bahan}

Alat-alat yang digunakan dalam penelitian ini yaitu mikropipet, pisau, tabung reaksi, mikroskop, gunting, GPS, cawan Petri, autoklaf, timbangan analitik, Erlenmeyer, mortar, pestle, jarum ose, mesin PCR, tangki elektroforesis, dan UVtransilluminator. Bahan-bahan yang digunakan dalam penelitian ini untuk isolasi bakteri yaitu daun tumbuhan F. minahassae, nutrien agar (NA), nutrient broth (NB), etanol $70 \%$, Air suling steril, natrium hipoklorit, kit isolasi DNA bakteri, dan kit PCR.

\section{Identifikasi Bakteri Endofit}

Sampel yang akan digunakan untuk identifikasi bakteri endofit yaitu daun tumbuhan langusei ( $F$. minahassae). Prosedur identifikasi bakteri endofit yang digunakan mengikuti prosedur yang diberikan oleh de Oliveira Costa et al. (2012) dengan modifikasi. Daun disterilkan permukaannya. Kemudian daun dibilas dengan air steril. Kemudian air bilasan cucian daun digunakan sebagai kontrol, disebarkan di atas media nutrient agar (NA) dan diinkubasi selama 3 hari pada suhu $37^{\circ} \mathrm{C}$. Media agar diperiksa apakah terdapat pertumbuhan koloni bakteri atau tidak.

Daun yang telah disterilisasi dipotong kecilkecil. Ekstrak jaringan diinkubasi pada $28^{\circ} \mathrm{C}$ selama 3 jam. Kemudian ekstrak disebarkan di atas permukaan media NA dan diinkubasi selama 3 hari pada suhu $37^{\circ} \mathrm{C}$. Setelah 3 hari, masing-masing koloni yang tumbuh dievaluasi. Koloni-koloni diidentifikasi secara makroskopik sesuai dengan morfologinya (warna, bentuk dan tepi). Masingmasing koloni yang dimurnikan dan berbeda dianggap sebagai isolat yang berbeda.

\section{Ekstraksi DNA dan amplifikasi gen 16S rRNA}

Ekstraksi DNA dilakukan menggunakan Plant Genomic DNA mini kit Geneaid GP100. Kondisi PCR yang digunakan yaitu: denaturasi awal pada $95^{\circ} \mathrm{C}$ selama 3 menit diikuti dengan 35 siklus yang terdiri atas denaturasi pada $95^{\circ} \mathrm{C}$ selama 30 menit, penempelan primer (annealing) pada $50^{\circ} \mathrm{C}$ selama 30 detik, dan elongasi pada $72^{\circ} \mathrm{C}$ selama 90 detik dan diikuti oleh elongasi akhir pada $72^{\circ} \mathrm{C}$ selama 1 menit. Hasil PCR diperiksa menggunakan 0,8\% agarose dan dielektroforesis kemudian divisualisasikan di bawah UV transilluminator. Produk hasil PCR dikirim ke penyedia jasa sekuensing 1st BASE Malaysia.

\section{Analisis filogenetik}

Hasil sekuensing yang berupa kromatogram yang diperoleh dari 1st BASE Malaysia diolah menggunakan tahapan seperti yang dianjurkan oleh Tallei dan Kolondam (2015). Kromatogram disunting menggunakan Geneious 10.1.3. Sebanyak kira-kira 50 nukleotida di bagian awal dan akhir dari sekuens yang mengandung primer dihilangkan. Kesalahan pembacaan pada kromatogram diperbaiki. Konsensus sekuens diperoleh dengan cara pairwise alignment dari sekuens forward dan reverse. Hasil sekuens yang telah diolah digunakan untuk mencari sekuens yang serupa di GenBank menggunakan metode BLAST nukleotida. Data-data sekuens yang serupa yang diperoleh dari GenBank kemudian dijajarkan menggunakan using multiple sequence aligment with hierarchical clustering yang dikembangkan oleh Corpet (1988) (http://multalin.toulouse.inra.fr/multalin/).

Sekuens-sekuens tersebut disamakan panjangnya untuk merekonstruksi pohon filogenetik menggunakan metode UPGMA yang terintegrasi di dalam Geneious10.1.3.

\section{Hasil dan Pembahasan \\ Identifikasi Bakteri Endofit}

Gambar 1 menampilkan daun tumbuhan langusei yang merupakan sumber dari bakteri endofit. Permukaan daun langusei memiliki rambutrambut yang panjang berwarna coklat kemerahan, terutama di bagian bawah daun. Daunnya berbentuk ovatus dengan panjang $10-20 \mathrm{~cm}$ dan pinggiran daun bergerigi. 

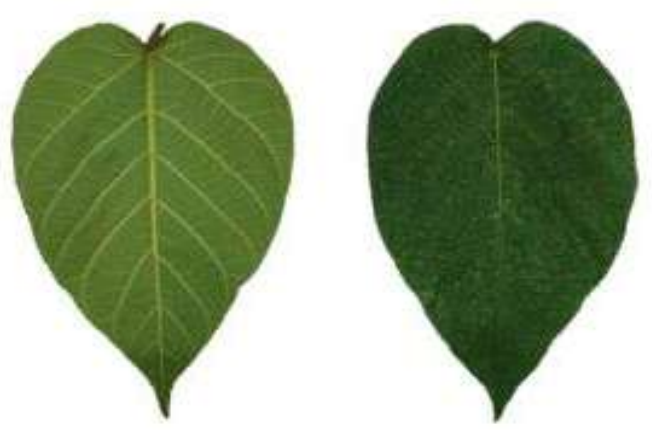

Gambar 1. Daun langusei (Ficus minahassae):

a) Tampak bawah; b) Tampak atas

Dari ekstrak jaringan tumbuhan langusei yang ditanam di media NA diperoleh dua koloni yang berbeda. Masing-masing koloni dimurnikan dan diidentifikasi secara makroskopik sesuai dengan morfologinya (warna, bentuk dan tepi). Kemudian diberi nama YL1 dan YL2. Isolat YL1 memiliki koloni dengan tepi yang tidak beraturan dan pigmen berwarna kuning. Isolat YL2 memiliki koloni yang berwarna krem (Tabel 1).

Tabel 1. Karakteristik morfologi bakteri

\begin{tabular}{cccc}
\hline Nama & \multicolumn{3}{c}{ Karakterisasi Morfologi } \\
\cline { 2 - 4 } & Warna & Bentuk & Tepi Koloni \\
& Koloni & Koloni & \\
YL1 & Kuning & Bulat & Tidak Beraturan \\
YL2 & Krem & Bulat & Licin \\
\hline
\end{tabular}

Identifikasi Bakteri Endofit Menggunakan Gen 16S rRNA

Gambar 2 menunjukkan hasil elektroforesis hasil PCR untuk sekuensing pada gel agarosa 0,8\%. Panjang fragmen hasil amplifikasi berada pada posisi 1000-1500 bp. Pita yang terang dari DNA kedua isolat menandakan bahwa kedua pita tersebut dapat disekuensing.

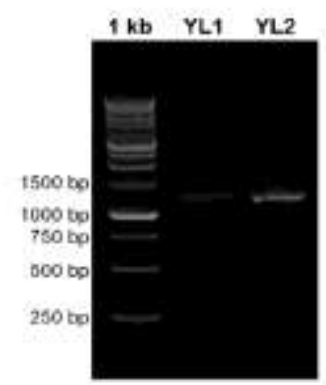

Gambar 2. Hasil PCR fragmen gen 16S rRNA dari isolat YL1 dan YL2.

Hasil sekeunsing yang telah disunting menggunakan piranti lunak Geneious 10.1.3. digunakan untuk mendapatkan sekuens yang memiliki kemiripan yang tinggi pada GenBank menggunakan metode BLAST nucleotide search. Hasil identifikasi menunjukkan bahwa isolat YL1 memiliki kemiripan $100 \%$ dengan Brachybacterium muris dan isolat YL2 memiliki kemiripan $99 \%$ dengan Pseudacidovorax intermedius.

\section{Analisis Filogenetik}

Konstruksi pohon filogenetik yang dilakukan menggunakan metode UPGMA (Gambar 3) yang terintegrasi pada piranti lunak Geneious memperlihatkan perbedaan taksa dari bakteri endofit yang ditemukan pada daun F. minahassae. Bakteri B. muris merupakan anggota dari filum actinobacteria, sedangkan $P$. intermedius merupakan anggota dari filum $\beta$-proteobacteria. Bakteri-bakteri endofit dari pohon ara yang dilaporkan sebelumnya merupakan anggotadari $\alpha$ proteobacteria, в-proteobacteria dan firmicutes. kebanyakan bakteri endofit pada umumnya merupakan anggota taksa actinobacteria, firmicutes, proteobacteria, $\beta$-proteobacteria dan $\gamma$ proteobacteria.

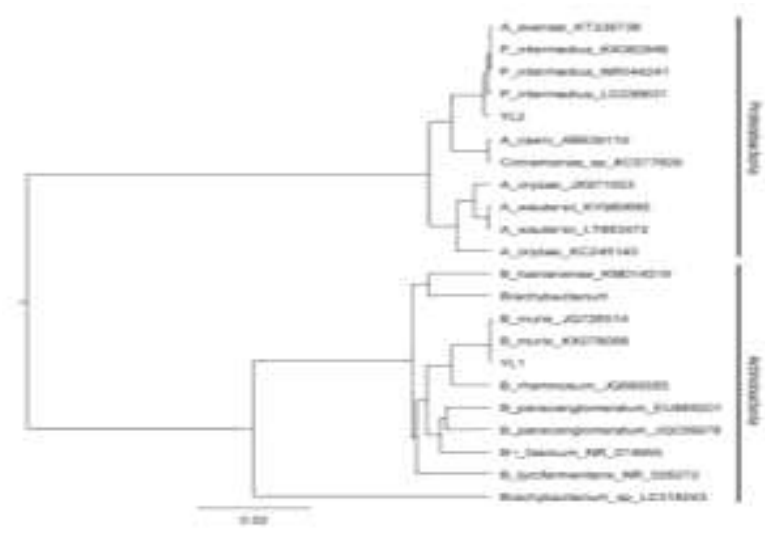

Gambar 3. Pohon filogenetik bakteri endofit yang diisolasi dari daun langusei, yang dikonstruksi menggunakan metode UPGMA. Sekuens bakteri endofit lainnya diperoleh dari GenBank yang ditandai dengan nomor aksesinya. YL1 adalah $B$. muris dan YL2 adalah $P$. intermedius.

\section{Kesimpulan}

Dari penelitian ini dapat disimpulkan yaitu Bakteri endofit yang terdapat pada daun Ficus minahassae yaitu YL1 memiliki kemiripan $100 \%$ dengan Brachybacterium muris dan YL2 memiliki kemiripan $99 \%$ dengan Pseudacidovorax intermedius. Dengan hasil analisis filogenetik Bakteri $P$. intermedius YL2 termasuk ke dalam filum proteobacteria, sedangkan dan $B$. muris YL1 termasuk ke dalam filum actinobacteria.

\section{Daftar Pustaka}

De Oliveira Costa, L.E., de Queiroz, M.V., Borges, A.C., de Moraes, C.A., de Araújo, E.F. 2012. Isolation and characterization of endophytic bacteria isolated from the leaves of the common bean (Phaseolus vulgaris). Brazilian J. Microb. 43(4):1562-1575. doi:10.1590/S1517838220120004000041.

Janda, J.M., Abbott, S.L.2007. 16S rRNA gene sequencing for bacterial identification in the diagnostic laboratory: pluses, perils, and pitfalls. J. Clin. Microbiol. 45(9):2761-2764. Doi: 10.1128/JCM.01228-07

Kandel, S.L., Joubert, P.M., Doty, S.L. 2017. Bacterial endophyte colonization and distribution within plants. Microorganisms. 
5(4):77.

doi:10.3390/microorganisms5040077.

Ma, Y.M., Liang, X.A., Zhang H.C., Liu, R. 2016. Cytotoxic and Antibiotic Cyclic Pentapeptide from an Endophytic Aspergillus tamarii of Ficus carica. J. Agric Food Chem. 64(19):3789-93. doi: 10.1021/acs.jafc.6b01051.

Muzzamal, H., Sarwar, R., Sajid, I., Hasnain, S. 2011. Isolation, identification and screening of endophytic bacteria antagonistic to biofilm formers. Pak. J. Zool. 44:249-257

Radji, M., 2005, Peranan Bioteknologi dan Mikroba Endofit Dalam Pengembangan Obat Herbal. Majalah IImu Kefarmasian. II, No.3, 113-126.

Smita V, Dipak V. 2015. Isolation and study of endophytes from leaves of Ficus racemosa $L$. Int. J. Res. Biosciences. 4(4):68-74.

Strobel, G., Daisy, B. 2003. Bioprospecting for microbial endophytes and their natural products. Microb. Mol. Biol. Rev. 67(4):491502. doi:10.1128/MMBR.67.4.491-502.2003.

Tallei, T.E., Kolondam, B.J. 2015. DNA barcoding of Sangihe nutmeg (Myristica fragrans) using matK gene. Hayati J. Biosciences. 22(1):41-47. doi:10.4308/hjb.22.1.41

Wilson, D. 1995, Endophyte: The evolution of a term, and clarification of its use and definition. Oikos. 73:274-276. doi: 10.2307/3545919.

Woese, C.R., Fox, G.E. 1977. Phylogenetic structure of the prokaryotic domain: the primary kingdoms. PNAS 74. (11): 5088-90. doi:10.1073/pnas.74.11.5088. 